\title{
Provisioning forest and conservation science with high-resolution maps of potential distribution of major European tree species under climate change
}

\author{
Debojyoti Chakraborty $^{1}$ (Dorbert Móricz ${ }^{2} \cdot$ Ervin Rasztovits $^{3} \cdot$ Laura Dobor $^{4} \cdot$ Silvio Schueler $^{1}$
}

Received: 29 July 2020 / Accepted: 10 January 2021 / Published online: 22 March 2021

(c) The Author(s) 2021

\begin{abstract}
-Key message We developed a dataset of the potential distribution of seven ecologically and economically important tree species of Europe in terms of their climatic suitability with an ensemble approach while accounting for uncertainty due to model algorithms. The dataset was documented following the ODMAP protocol to ensure reproducibility. Our maps are input data in a decision support tool "SusSelect" which predicts the vulnerability of forest trees in climate change and recommends adapted planting material. Dataset access is at $\mathrm{https} / / / \mathrm{doi} .0 \mathrm{rg} / 10.5281 / \mathrm{zenodo} .3686918$. Associated metadata are available at https://metadata-afs.nancy.inra.fr/geonetwork/srv/fre/catalog.search\#/metadata/fe 79a36d6db8-4a87-8a9f-c72a572b87e8.
\end{abstract}

Keywords biomod $2 \cdot$ Ensemble species distribution model $\cdot$ ODMAP

\section{Background}

Climate change is likely to cause widespread shifts in the composition and range of plant communities worldwide (Scheffers et al. 2016). For long-living communities such as forests, such change may lead to a drastic decline in their ability to support multiple ecosystem services (Maroschek et al. 2009; Härtl et al. 2016; Mina et al.

Handling Editor: Marianne Peiffer

Contribution of the co-authors DC: running the data analysis, writing the paper, SS: Research conception, coordination, and supervision writing the paper, NM: Initial model runs, ER: Initial model runs, LD: climate data provision

Debojyoti Chakraborty

debojyoti.chakraborty@bfw.gv.at

1 Austrian Research Centre for Forests, Seckendorff-Gudent Weg. 8, 1131 Vienna, Austria

2 Department of Ecology and Forest Management, Forest Research Institute, Sárvár, 9600 Sopron, Hungary

3 Sopron, Hungary

4 Faculty of Forestry and Wood Sciences, Czech University of Life Sciences Prague, Kamýcká 129, 16521 Prague 6, Czech Republic
2017). In Europe, the effects of climate change on forests may include changes in forest productivity (Reyer et al. 2014), changes in the distribution of tree species (Dyderski et al. 2018; Thurm et al. 2018), the economic value of forests (Hanewinkel et al. 2013), effects of intensifying disturbance regimes (Seidl et al. 2011, 2014), and droughts (Allen et al. 2010).

As such, there has been considerable interest in estimating the potential distribution of tree species under scenarios of climate change. Species distribution models (SDMs), often referred to as ecological niche models (ENMs), are the most widely used tools for this purpose (Sykes et al. 1996; Zimmermann et al. 2010; Guisan et al. 2013; Dyderski et al. 2018), because they predict the potential distribution of species by exploiting the correlation between the known occurrence of a species and corresponding environmental conditions.

In the recent decades, SDMs have evolved and were applied for a wide range of questions such as to predict species range in the future (Sykes et al. 1996; Thuiller et al. 2008; Dyderski et al. 2018), to test hypotheses about species distribution limits (Kreyling et al. 2015), to develop conservation and management strategies in climate change (Guisan et al. 2013; Hamann and Aitken 2013; Mcshea 2014; Schueler et al. 2014), and understand the role of genetic variation in tree species distributions ( $\mathrm{O}^{\prime}$ Neill et al. 
2008; Benito Garzón et al. 2011; Valladares et al. 2014; Chakraborty et al. 2019; Garate-Escamilla et al. 2019).

Despite the recent improvements and widespread use, the free and unrestricted utilization of SDMs in the applied forest and conservation science is often limited due to inadequate documentation and reporting of the predictions and uncertainties. Therefore, Zurell et al. (2020) proposed a reporting protocol known as ODMAP (Overview, Data, Model, Assessment, and Prediction), which offers a standardized way of communicating the results/outputs from SDMs by describing the objectives, model assumptions, scaling issues, data sources, model workflow, model predictions, and uncertainty.

Here we present a dataset on the potential distribution of seven widely occurring tree species of Europe for current and projected future climate scenarios. To ensure transparent reporting and reproducibility, we described the dataset according to the ODMAP protocol suggested by Zurell et al. (2020). The following sections describe the basic elements of the dataset, while the detailed metadata according to ODMAP (Zurell et al. 2020) is presented in Table 2 in Appendix.

\section{Methods}

\subsection{Species occurrence data}

Current occurrence (presence and absence) of seven major stand forming tree species in Europe (Table 1) was obtained from the EU-Forest dataset (Mauri et al. 2017). These species are known to form stands in a wide range of forest types across Europe (European Environmental Agency 2006) and are also economically important (Hanewinkel et al. 2013). The Mauri et al. (2017) dataset is one of the most exhaustive, harmonized European tree species occurrence (presence) data available till date, which combines three existing datasets: the Forest Focus (Hiederer et al. 2011), Biosoil (Houston Durrant et al. 2011), and national forest inventories. In our case, the geographic locations of the target species in the EU-Forest dataset were assumed to be true presences, while the presence locations of other target species were assumed to be the absence locations. To ensure that the absence locations are not only climatically dissimilar but also geographically distant from the observed presence locations, we developed the so-called pseudoabsences according to Senay et al. (2013). This is a three-step approach: (i) specifying a geographical extent outside the observed presences, (ii) environmental profiling of the absences outside this geographic extent, and (iii) $k$-means clustering of the environmental profiles and selecting random samples within each cluster. In our case, a 2-degree buffer was found to be optimum following Senay et al. (2013). The absence locations outside this geographic extent were classified into 10-15 environmentally dissimilar clusters according to the $k$-means clustering algorithm. The numbers of absence clusters for each species were determined from the elbow of the plot of total within-cluster sum of square (WSS) and number of clusters. The number of pseudoabsence locations was further reduced by randomly selecting a sample of locations defined by the $95 \%$ confidence interval from each of the absence clusters. This approach was used
Table 1 Occurrence (presence and absence points) for the seven tree species obtained from Mauri et al. (2017) and model evaluation statistics. The model evaluation based on mean ROC, TSS, sensitivity, and specificity of the models used to develop the ensemble predictions. For detailed model evaluation see Table 5 for the seven tree species

\begin{tabular}{|c|c|c|c|c|c|c|c|}
\hline \multirow[b]{2}{*}{ Species } & \multicolumn{2}{|c|}{ Occurrence data } & \multicolumn{5}{|c|}{ Model evaluation } \\
\hline & Presence & Absence & Criteria & Testing data & Evaluating data & Sensitivity & Specificity \\
\hline A alba & 9895 & 579,088 & ROC & 0.98 & 0.98 & 94.74 & 96.67 \\
\hline F sylvatica & 38,693 & 550,290 & $\mathrm{ROC}$ & 0.95 & 0.95 & 92.09 & 88.19 \\
\hline$L$ decidua & 14,747 & 574,236 & $\mathrm{ROC}$ & 0.96 & 0.96 & 94.06 & 92.28 \\
\hline$P$ abies & 61,210 & 527,773 & $\mathrm{ROC}$ & 0.95 & 0.95 & 93.47 & 90.08 \\
\hline$P$ sylvestris & 70,852 & 518,131 & ROC & 0.94 & 0.94 & 93.03 & 87.01 \\
\hline$Q$ petraea & 20,929 & 568,054 & $\mathrm{ROC}$ & 0.94 & 0.94 & 91.74 & 86.45 \\
\hline$Q$ robur & 24,809 & 564,174 & $\mathrm{ROC}$ & 0.97 & 0.97 & 92.96 & 93.36 \\
\hline A alba & 9895 & 579,088 & TSS & 0.92 & 0.91 & 94.78 & 96.44 \\
\hline F sylvatica & 38,693 & 550,290 & TSS & 0.81 & 0.80 & 91.79 & 88.40 \\
\hline L decidua & 14,747 & 574,236 & TSS & 0.86 & 0.86 & 94.19 & 92.02 \\
\hline$P$ abies & 61,210 & 527,773 & TSS & 0.84 & 0.83 & 93.16 & 90.32 \\
\hline$P$ sylvestris & 70,852 & 518,131 & TSS & 0.80 & 0.80 & 93.18 & 86.72 \\
\hline$Q$ petraea & 20,929 & 568,054 & TSS & 0.79 & 0.78 & 91.83 & 86.19 \\
\hline$Q$ robur & 24,809 & 564,174 & TSS & 0.86 & 0.86 & 93.21 & 93.04 \\
\hline
\end{tabular}


to generate pseudo-absence for all seven species. The resultant dataset was used to calibrate the SDMs with the biomod2 platform (Thuiller et al. 2016).

\subsection{Climate data}

Biologically relevant climate variables were obtained from the ECLIPS 2.0 dataset (Chakraborty et al. 2020a, b). This dataset was developed from dynamically downscaled, and bias-corrected regional climate model results from the EURO-CORDEX with a resolution of 30 arcsec. The EURO-CORDEX (www.eurocordex.net) is an initiative of the World Climate Research Program (Giorgi et al. 2009) for coordinating dynamic regional downscaling of the global climate projections from the CMIP5 (Coupled Model Intercomparison Project Phase 5) (Jacob et al. 2014). All projections were corrected for bias using a distribution scaling method (Yang et al. 2010) to produce $0.11 \times 0.11^{\circ}$ resolution gridded data for daily mean, minimum, and maximum nearsurface air temperature and precipitation. We further refined this $0.11 \times 0.11^{\circ}$ resolution bias-corrected data to 30 arcsec using the delta algorithm for spatial downscaling (Ramirez-Villegas and Jarvis 2010; Moreno and Hasenauer 2016). With this approach, we developed a gridded dataset for 80 climate variables (Table 3 in Appendix) for historic climate (1961-1990) and three future time frames which include averages of (2041-2060, 2061-2080, and 2081-2100) for two Representative Concentration Pathway (van Vuuren et al. 2011), RCP 4.5 and RCP 8.5. The RCP 4.5 or the moderate scenario assumes a $650-\mathrm{ppm}$ atmospheric $\mathrm{CO}_{2}$ concentration and a $1.0-2.6-^{\circ} \mathrm{C}$ increase in annual temperature by 2100 , whereas in RCP 8.5 , a pessimistic scenario assumes a $1350-\mathrm{ppm} \mathrm{CO}_{2}$ and $2.6-4.8-{ }^{\circ} \mathrm{C}$ increase in annual temperature by 2100 (van Vuuren et al. 2011). The ECLIPS 2.0 dataset is available at https://doi. org/10.5281/zenodo.3952159.

\subsection{Variable selection}

From the list of potential predictor variables (Table 3 in Appendix), the ones which explain most of the variation in the observed presence and absences of each species were selected with a recursive feature elimination approach (RFE) implemented within the Random forest algorithm (Breiman 2001). Within the RFE approach, the variables were eliminated iteratively, starting from the full set of potential predictors and retaining only those variables that reduce the mean square error over random permutations of the same variable. The variables which were linearly correlated with other variables and had a variance inflation factors $\mathrm{VIF}>5$, a commonly used threshold in detecting mulicollinearity (Craney and Surles 2002; Thompson et al. 2017), were identified. The identified collinear variables with the lower value according to the Akaike Information Criteria (AIC) (Akaike 1974) were retained for further model development. This subset of uncorrelated climate variables (Table 4 in Appendix) was used as predictor variables for developing the ensemble species distribution models.

\subsection{Ensemble species distribution models}

To model the potential distribution of the seven European tree species, an ensemble distribution modeling approach, implemented through the R package, biomod2 (Thuiller et al. 2016), was used. biomod2 offers a computational platform for multi-method modeling that generates models of species' potential distribution for each species. The model algorithms include GLM (Generalized Linear Models), GAM (Generalized Additive Models), GBM (Generalized Boosted regression Models), CTA (Classification Tree Analysis), ANN (Artificial Neural Networks), SRE (Surface Range Envelop or BIOCLIM), FDA (Flexible Discriminant Analysis), MARS (Multivariate Adaptive Regression Spline), RF (Random Forest for classification and regression), and MAXENT. Tsuruoka. Hence, biomod 2 combines the strengths of multiple modeling algorithms while accounting for their uncertainties. We used biomod 2 default settings for all the modeling algorithms (Thuiller et al. 2016). Each model algorithm predicted the probability of the potential distribution for each species. Such probabilities predicted from the individual models were ensembled into a consensus model by combining the median probability over the selected models with true skill statistics threshold (TSS > 0.7) (Allouche et al. 2006; Coetzee et al. 2009). The median was chosen because it is known to be less sensitive to outliers than the mean. The estimated ensemble model predictions were presented as GeoTIFF rasters. These raster files are available at https://doi. org/10.5281/zenodo.3686918. 


\subsection{Model evaluation and uncertainty analysis}

Model evaluation was carried by splitting the occurrence dataset into $75 \%$ for model training and $25 \%$ for model testing. Besides, biomod 2 allows specifying the number of runs for each combination of training and testing data. Therefore, 10 independent runs, each with a randomly selected set of training and test data, were implemented.

For each such model run as well as the final ensemble models, the model evaluation statistics were recorded. These statistics were true skill statistics (TSS) and area under the relative operating characteristic (ROC), model sensitivity (the ability of the model to predict true presences), and model specificity (the ability of the model to predict the true absences). TSS takes into account both omission and commission errors and ranges also from -1 to +1 , not being affected by prevalence as KAPPA (Allouche et al. 2006). TSS values ranging from 0.2 to 0.5 were considered poor, from 0.6 to 0.8 useful, and values larger than 0.8 were good to excellent (e.g., Coetzee et al. 2009). Prediction accuracy is considered to be similar to random for ROC values lower than 0.5 ; poor, for values in the range $0.5-0.7$; fair in the range $0.7-0.9$; and excellent for values greater than 0.9 (Pontius and Parmentier 2014).

Model uncertainty was also estimated in terms of coefficient of variation (CV) among the predictions of the individual models. The estimated CVs are also presented as GeoTIFF rasters where each cell corresponds to a $\mathrm{CV}$ value, whereby higher and lower $\mathrm{CV}$ values indicate higher and lower uncertainties, respectively, in the ensemble model. These raster files are available at https:// doi.org/10.5281/zenodo.3686918.

In addition to internal evaluation, the model predictions were also tested against independent data on European Forest Genetic Conservation Units (GCU) (Lefèvre et al. 2013). The geographic locations of the 3354 genetic conservation units (Fig. 3 in Appendix) were used to extract the predicted probability of occurrence from the models for the seven target species for the period 1961-1990. The ensemble models were used to predict the distribution of the seven target species at each GCU location. Predicted probability $<60$ were assumed to be, "incorrectly predicted," whereas those $>60 \%$ were treated as "correctly predicted" following Dyderski et al. (2018). For most species, the incorrectly classified GCUs are those located in the southeastern part of their potential distribution (Fig. 3 in Appendix).

\section{Access to the data and metadata description}

The dataset is accessible through https://doi.org/10.5281/ zenodo.3686918. Associated metadata are available at https:// metadata-afs.nancy.inra.fr/geonetwork/srv/fre/catalog. search\#/metadata/fe79a36d-6db8-4a87-8a9f-c72a572b87e8

\section{Technical validation}

In general, for all species, a high correlation was observed between the predictive performance of the models calibrated with both training and evaluation data with mean TSS ranging from 0.79 to 0.92 and mean ROC ranging from 0.92 to 0.98 (Table 1). Average sensitivity or the ability of the models to predict true presences across all species and models range from 95 to $98 \%$ and average specificity or the ability of the models to predict true absences range 86-96\% (Table 1). Detailed performance of individual models can be found in Table 5 in Appendix.

Model evaluation against independent data reveals that out of the total $3354,80-96 \%$ of the species occurrence in the European genetic conservation unit (GCU) dataset was correctly predicted by our ensemble SDMs (Table 6 in Appendix).

The ensemble SDMs predicts a substantial change in the potential distribution of the seven target species (Fig. 1). A general trend of a northward shift in potential climate suitability (probability $>60 \%$ ) was predicted, as also observed by recent studies such as Dyderski et al. (2018). Median uncertainty represented by the coefficient of variation between individual models varies between 6 and 15\% and with Larix decidua and Abies alba having higher prediction uncertainty compared to other species (Fig. 2).

\section{Reuse potential and limits}

The dataset is currently being used to develop a decision support tool, SusSelect Smartphone app https://play.google. $\mathrm{com} /$ store/apps/details?id=com.topolynx.susselect\&hl=en, which calculates the vulnerability of tree species under climate change. The dataset is also being used to develop an Integrated Toolbox that combines tools from Interreg CE, Horizon 2020, and EU Life projects. This integrated toolbox (TEACHER-CE) is under development and focuses on climate-proof management of water-related issues such as floods, heavy rain, and drought risk prevention, small water retention measures, and protection of water resources through sustainable land-use management. For details see: https:// www.interreg-central.eu/Content.Node/TEACHER-CE.html. 
Fig. 1 Potential distribution of seven European tree species under the historical period (1961-1990) and predicted future scenario of 2080-2100 under RCP 4.5 and RCP 8.5
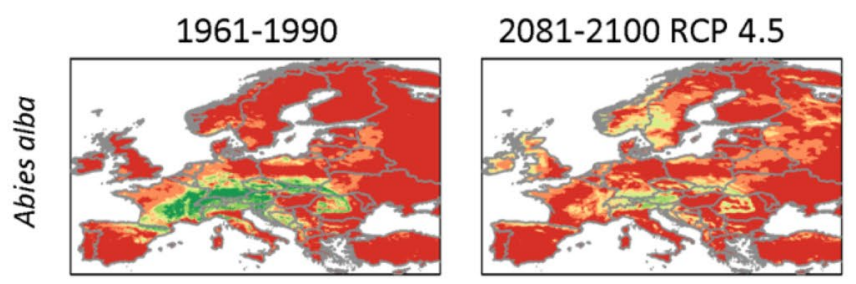

2081-2100 RCP 8.5
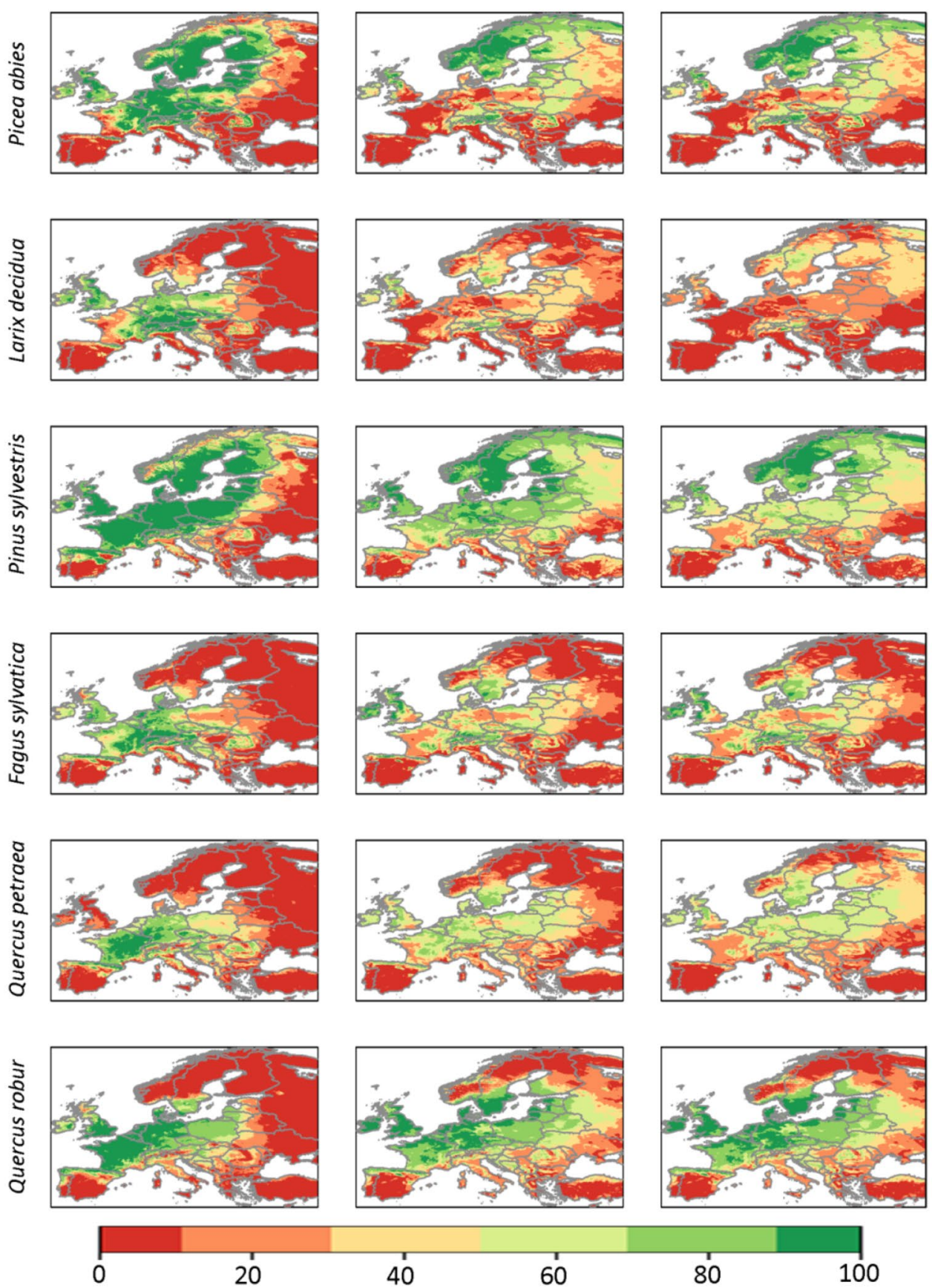

INRAC פ Springer 

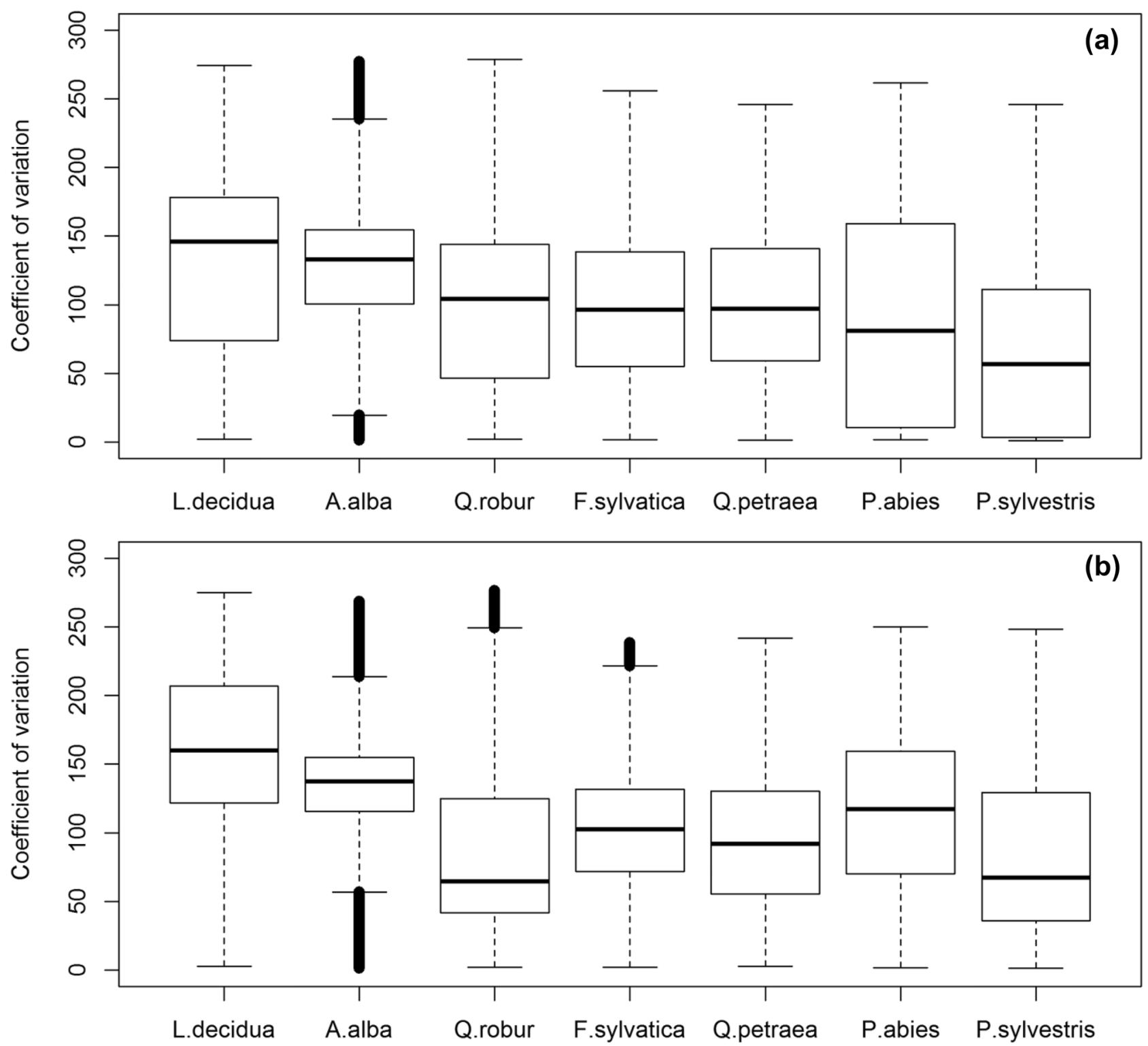

Fig. 2 Uncertainly of predictions for the seven target tree species under a current climate (1961-90) and b RCP 8.5 (1981-2100) expressed as the coefficient of variation

Ecological niche models or SDMs assume that the relation between climatic drivers and the species distribution remains constant also in climate change. This assumption needs to be taken into account while interpreting the results of the paper.

\section{Dataset citation}

Chakraborty D, Móricz N, Rasztovits E, Dobor L, Schueler S (2020). Provisioning forest and conservation science with European tree species distribution models under climate change (Version v1) [data set]. Zenodo. http://doi.org/10. 5281/zenodo.3686918

\section{Appendix}

Provisioning forest and conservation science with highresolution maps of potential distribution of major European tree species under climate change. 
Table 2 Description of the dataset according to the ODMAP protocol

\begin{tabular}{|c|c|}
\hline ODMAP elements & Contents \\
\hline \multicolumn{2}{|l|}{ Overview } \\
\hline Authorship & $\begin{array}{l}\text { Authors: Debojyoti Chakraborty, Norbert Móricz, Ervin Rasztovits, Laura Dobor, Silvio Schueler } \\
\text { Contact email: debojyoti.chakraborty@bfw.gv.at } \\
\text { Title: } \\
\text { DOI: }\end{array}$ \\
\hline Model objective & $\begin{array}{l}\text { SDM Objective: forecast/transfer } \\
\text { Target output: probability of occurrence of target tree species }\end{array}$ \\
\hline Taxon & $\begin{array}{l}\text { Seven tree species of Europe: } \\
\text { Abies alba, Fagus sylvatica, Larix decidua, Picea abies, Pinus sylvestris, Quercus petraea, Quercus robur }\end{array}$ \\
\hline Location & Europe \\
\hline Scale of analysis & $\begin{array}{l}\text { Spatial extent (Lon/ Lat): } \\
\text { Longitude: }-32.65000^{\circ} \mathrm{E},-69.44167^{\circ} \mathrm{E} \\
\text { Latitude: } 30.877982^{\circ} \mathrm{N},-71.57893^{\circ} \mathrm{N} \\
\text { Spatial resolution: } 30 \text { arcsec } \\
\text { Temporal resolution: We modeled for historic climate (1961-1990) and three future time frames which include aver- } \\
\text { ages of (2041-2060, } 2061-2080 \text {, and } 2081-2100) \text {. The predictions were done for two Representative Concentra- } \\
\text { tions RCP } 4.5 \text { and RCP } 8.5\end{array}$ \\
\hline Biodiversity data overview & $\begin{array}{l}\text { Observation type: standardized monitoring } \\
\text { Response data type: presence/absence data }\end{array}$ \\
\hline Type of predictors & Climatic \\
\hline Conceptual model/hypotheses & $\begin{array}{l}\text { A large body of scientific studies indicate that climate is one of the major drivers of the distribution of tree species } \\
\text { at the continental scale. We exploited this correlation between species' current occurrence and climate to develop } \\
\text { SDMs that predict the potential distribution of the target tree species }\end{array}$ \\
\hline Assumptions & $\begin{array}{l}\text { We assumed that species are at pseudo-equilibrium with the environment. The source of the presence/absence data } \\
\text { (Mauri et al. 2017) used in this study is largely from national forest inventories where tree individuals below a } \\
\text { certain diameter at breast height are not recorded. We assume that this data collection procedure did not bias our } \\
\text { occurrence data } \\
\text { Since our occurrence dataset covers the whole current distribution of the target species, which represents both cur- } \\
\text { rent and likely future climate of Europe, we safely assumed that the species retain their niches across space and } \\
\text { time and the current occurrence climate correlation remains stable when predicting the models for future climate }\end{array}$ \\
\hline SDM algorithms & $\begin{array}{l}\text { Algorithms: We selected } 10 \text { modeling algorithms: GLM (Generalized Linear Models), GAM (Generalized Additive } \\
\text { Models), GBM (Generalized Boosted regression Models), CTA (Classification Tree Analysis), ANN (Artificial } \\
\text { Neural Networks), SRE (Surface Range Envelop or BIOCLIM), FDA (Flexible Discriminant Analysis), MARS } \\
\text { (Multivariate Adaptive Regression Spline), RF (Random Forest for classification and regression), and MAXENT. } \\
\text { Tsuruoka. These model algorithms were implemented through an ensemble model platform biomod2 (Thuiller } \\
\text { et al. 2016) } \\
\text { Model complexity: The individual models were run using the standard default settings of biomod2 that are designed } \\
\text { to balance model complexity and overfitting } \\
\text { Ensembles: The prediction of individual model algorithms were ensembled through biomod2 (Thuiller et al. 2016) }\end{array}$ \\
\hline
\end{tabular}


Table 2 (continued)

\begin{tabular}{|c|c|}
\hline ODMAP elements & Contents \\
\hline Model workflow & $\begin{array}{l}\text { The model workflow includes the following: } \\
\text { 1. Data cleaning and generation of pseudo absences } \\
\text { 2. Finding the best climate variables to fit the models } \\
\text { 2. Model running through biomod } 2 \text { platform } \\
\text { 3. Ensemble prediction } \\
\text { 4. Generation of the maps as gridded } 30 \text { arcsec rasters }\end{array}$ \\
\hline Software & $\begin{array}{l}\text { Software: All analyses were conducted using R version } 3.3 .2 \text { (R Core Team 2016). Packages used: biomod2 (Thu- } \\
\text { iller et al. 2016), Random Forest (Breiman 2001), } \\
\text { Data availability: } \\
\text { Presence absence data are available from Mauri et al. (2017) } \\
\text { Climate data is available from } \\
\text { Chakraborty D, Dobor L, A, Hlásny T, Schueler S (2020) } \\
\text { High-resolution gridded climate data for Europe based on bias-corrected EURO-CORDEX: the ECLIPS-2.0 dataset } \\
\text { [Zenodo: https://doi.org/10.5281/zenodo.3952159.] }\end{array}$ \\
\hline \multicolumn{2}{|l|}{ Data } \\
\hline Biodiversity data & 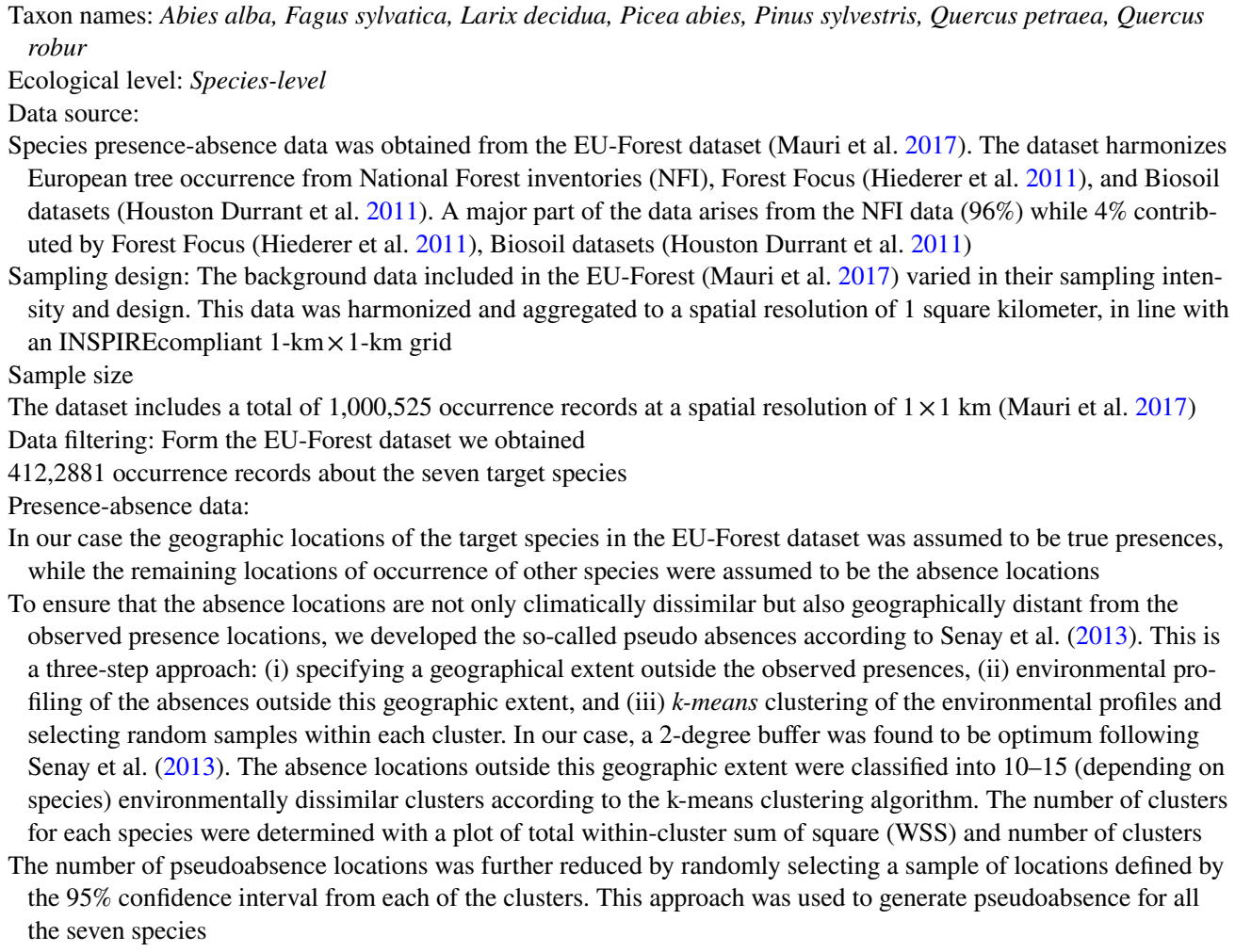 \\
\hline Data partitioning & $\begin{array}{l}\text { The occurrence dataset for each target species was partitioned by splitting into } 75 \% \text { for model training and } 25 \% \text { for } \\
\text { model evaluation }\end{array}$ \\
\hline Environmental predictors & $\begin{array}{l}\text { Predictor variables } \\
\text { Environmental predictors were } 80 \text { biologically relevant climate variables comprising of annual, seasonal, and } \\
\text { monthly variables } \\
\text { From this list of } 80 \text { variables, a small subset of potential predictor variables was selected for each target species dur- } \\
\text { ing the variable selection process } \\
\text { Data sources: } \\
\text { The spatial resolution of predictor data: } 30 \text { arcsec which is roughly equivalent to } 1 \times 1 \mathrm{~km} \text { or lower depending on } \\
\text { latitude } \\
\text { The temporal resolution of predictor variable: Historic climate (1961-1990) and three future time frames which } \\
\text { include averages of (2041-2060, 2061-2080, and 2081-2100) for two Representative Concentration RCP } 4.5 \text { and } \\
\text { RCP } 8.5 \text { were used for the SDM predictions } \\
\text { Geographic projection: WGS } 84 \text { (EPSG: } 4326)\end{array}$ \\
\hline Model & \\
\hline
\end{tabular}


Table 2 (continued)

\begin{tabular}{|c|c|}
\hline ODMAP elements & Contents \\
\hline $\begin{array}{l}\text { Variable selection and multi- } \\
\text { collinearity }\end{array}$ & $\begin{array}{l}\text { From the list of potential predictor variables (Table } 2 \text { in Appendix), the ones which explain most of the variation in } \\
\text { the observed presence and absences of each species were selected with a recursive feature elimination approach } \\
\text { (RFE) implemented within the Random forest algorithm (Breiman 2001). Within the RFE approach, the variables } \\
\text { were eliminated iteratively, starting from the full set of potential predictors (Table } 2 \text { in Appendix), and retaining } \\
\text { only those variables that reduce the mean square error over random permutations of the same variable. The vari- } \\
\text { ables which were linearly correlated with other variables and had a variance inflation factors VIF }>5 \text { as suggested } \\
\text { by Booth et al. (1994) were identified, and the ones with the lower value according to the Akaike Information Crite- } \\
\text { ria (AIC) (Akaike 1974) were retained for further model development. This subset of uncorrelated climate variables } \\
\text { (Table } 3 \text { in Appendix) was used as predictor variables for developing the ensemble species distribution models }\end{array}$ \\
\hline Model settings & The models were run with the default settings of biomod2 (Thuiller et al. 2016) \\
\hline Model estimates & $\begin{array}{l}\text { The models estimated median ensemble probability of species occurrence and associated model uncertainty repre- } \\
\text { sented by the coefficient of variation }\end{array}$ \\
\hline Model ensemble & $\begin{array}{l}\text { Predicted probabilities from the individual models for each target species were ensembled as a consensus model } \\
\text { which combined the median probability over the selected models with true skill statistics threshold (TSS > 0.7) } \\
\text { (Allouche et al. 2006; Coetzee et al. 2009) }\end{array}$ \\
\hline Threshold selection & $\begin{array}{l}\text { True skill statistics threshold (TSS > 0.7), a commonly used threshold for SDMS (Allouche et al. 2006; Coetzee } \\
\text { et al. 2009), was used }\end{array}$ \\
\hline \multicolumn{2}{|l|}{ Assessment } \\
\hline Model performance statistics & $\begin{array}{l}\text { For each such model run as well as the final ensemble models for each target species, the model evaluation statistics } \\
\text { were recorded. These statistics were true skill statistics (TSS) and area under the relative operating characteristic } \\
\text { (ROC), model sensitivity (the ability of the model to predict true presences), and model specificity (the ability of } \\
\text { the model to predict the true absences). TSS takes into account both omission and commission errors and ranges } \\
\text { also from }-1 \text { to }+1 \text {, not being affected by prevalence as KAPPA (Allouche et al. 2006). TSS values ranging from } \\
0.2 \text { to } 0.5 \text { were considered poor, from } 0.6 \text { to } 0.8 \text { useful, and values larger than } 0.8 \text { were good to excellent (e.g. } \\
\text { Coetzee et al. 2009). Prediction accuracy is considered to be similar to random for ROC values lower than 0.5; } \\
\text { poor, for values in the range } 0.5-0.7 \text {; fair in the range } 0.7-0.9 \text {; and excellent for values greater than } 0.9 \text { (Pontius } \\
\text { and Parmentier 2014) }\end{array}$ \\
\hline \multicolumn{2}{|l|}{ Prediction } \\
\hline Prediction output & $\begin{array}{l}\text { Predicted probabilities from the individual models and target species were ensembled as a consensus model } \\
\text { which combined the median probability over the selected models with true skill statistics threshold (TSS > 0.7) } \\
\text { (Allouche et al. 2006; Coetzee et al. 2009). The median was chosen because it is known to be less sensitive to } \\
\text { outliers than the mean. The estimated ensemble model predictions were presented as GeoTIFF rasters }\end{array}$ \\
\hline Uncertainty quantification & $\begin{array}{l}\text { Model uncertainty was estimated in terms of coefficient of variation }(\mathrm{CV}) \text { among the predictions of the individual } \\
\text { models. The estimated CVs are also presented as GeoTIFF rasters where each cell corresponds to a CV value } \\
\text { whereby higher and lower CV values indicate higher and lower uncertainty respectively in the ensemble model }\end{array}$ \\
\hline
\end{tabular}


Table 3 Potential climate variables from the ECLIPS 2.0 dataset (Chakraborty et al. 2020a, b) used to calibrate the ensemble SDMs

\begin{tabular}{|c|c|c|}
\hline Climate variable & Variables & Unit \\
\hline AHM & Annual heat: moisture index $(\mathrm{MAT}+10) /(\mathrm{MAP} / 1000))$ & \\
\hline bFFP & The Julian date on which FFP begins & \\
\hline DDabove18 & Degree-days below $18^{\circ} \mathrm{C}$, heating degree-days & \\
\hline DDabove5 & Degree-days above $5^{\circ} \mathrm{C}$, growing degree-days & \\
\hline DDbelow0 & Degree-days below $0{ }^{\circ} \mathrm{C}$, chilling degree-days & \\
\hline DDbelow18 & Degree-days below $18{ }^{\circ} \mathrm{C}$, heating degree-days & \\
\hline eFFP & The Julian date on which FFP ends & \\
\hline EMT & Extreme minimum temperature over 30 years & ${ }^{\circ} \mathrm{C}$ \\
\hline FFP & Frost-free period & Days \\
\hline MAP & Mean annual precipitation $(\mathrm{mm})$ & ${ }^{\circ} \mathrm{C}$ \\
\hline MAT & Mean annual temperature $\left({ }^{\circ} \mathrm{C}\right)$ & ${ }^{\circ} \mathrm{C}$ \\
\hline MCMT & Mean coldest month temperature $\left({ }^{\circ} \mathrm{C}\right)$ & ${ }^{\circ} \mathrm{C}$ \\
\hline MSP & Mean summer (May to Sept.) precipitation (mm) & ${ }^{\circ} \mathrm{C}$ \\
\hline MWMT & Mean warmest month temperature $\left({ }^{\circ} \mathrm{C}\right)$ & ${ }^{\circ} \mathrm{C}$ \\
\hline NFFD & The number of frost-free days & days \\
\hline PPT_at & Autumn precipitation (mm) & $\mathrm{mm}$ \\
\hline PPT_sm & Summer precipitation (mm) & $\mathrm{mm}$ \\
\hline PPT_sp & Spring precipitation $(\mathrm{mm})$ & $\mathrm{mm}$ \\
\hline PPT_wt & Winter precipitation $(\mathrm{mm})$ & $\mathrm{mm}$ \\
\hline РPT01 & Precipitation month 01 & $\mathrm{~mm}$ \\
\hline РPT02 & Precipitation month 02 & $\mathrm{~mm}$ \\
\hline РРT03 & Precipitation month 03 & $\mathrm{~mm}$ \\
\hline РPT04 & Precipitation month 04 & $\mathrm{~mm}$ \\
\hline РPT05 & Precipitation month 05 & $\mathrm{~mm}$ \\
\hline РPT06 & Precipitation month 06 & $\mathrm{~mm}$ \\
\hline РPT07 & Precipitation month 07 & $\mathrm{~mm}$ \\
\hline РРT08 & Precipitation month 08 & $\mathrm{~mm}$ \\
\hline РPT09 & Precipitation month 09 & $\mathrm{~mm}$ \\
\hline PPT10 & Precipitation month 10 & $\mathrm{~mm}$ \\
\hline PPT11 & Precipitation month 11 & $\mathrm{~mm}$ \\
\hline PPT12 & Precipitation month 12 & $\mathrm{~mm}$ \\
\hline SHM & Summer heat: moisture index ((MWMT)/(MSP/1000)) & \\
\hline Tave_at & Autumn (Sep.-Nov.) mean temperature $\left({ }^{\circ} \mathrm{C}\right)$ & ${ }^{\circ} \mathrm{C}$ \\
\hline Tave_sm & Summer (Jun.-Aug.) mean temperature $\left({ }^{\circ} \mathrm{C}\right)$ & ${ }^{\circ} \mathrm{C}$ \\
\hline Tave_sp & Spring (Mar.-May) mean temperature $\left({ }^{\circ} \mathrm{C}\right)$ & ${ }^{\circ} \mathrm{C}$ \\
\hline Tave_wt & Winter (Dec. (prev. yr)-Feb.) mean temperature $\left({ }^{\circ} \mathrm{C}\right)$ & ${ }^{\circ} \mathrm{C}$ \\
\hline Tave01 & Average temperature month 01 & ${ }^{\circ} \mathrm{C}$ \\
\hline Tave02 & Average temperature month 02 & ${ }^{\circ} \mathrm{C}$ \\
\hline Tave03 & Average temperature month 03 & ${ }^{\circ} \mathrm{C}$ \\
\hline Tave04 & Average temperature month 04 & ${ }^{\circ} \mathrm{C}$ \\
\hline Tave05 & Average temperature month 05 & ${ }^{\circ} \mathrm{C}$ \\
\hline Tave06 & Average temperature month 06 & ${ }^{\circ} \mathrm{C}$ \\
\hline Tave07 & Average temperature month 07 & ${ }^{\circ} \mathrm{C}$ \\
\hline Tave08 & Average temperature month 08 & ${ }^{\circ} \mathrm{C}$ \\
\hline Tave09 & Average temperature month 09 & ${ }^{\circ} \mathrm{C}$ \\
\hline Tave10 & Average temperature month 10 & ${ }^{\circ} \mathrm{C}$ \\
\hline Tave11 & Average temperature month 11 & ${ }^{\circ} \mathrm{C}$ \\
\hline Tave12 & Average temperature month 12 & ${ }^{\circ} \mathrm{C}$ \\
\hline TD & Temperature difference between MWMT and $\operatorname{MCMT}\left({ }^{\circ} \mathrm{C}\right)$ & ${ }^{\circ} \mathrm{C}$ \\
\hline Tmax_an & Maximum yearly temperature & ${ }^{\circ} \mathrm{C}$ \\
\hline Tmax_at & Maximum autumn temperature & ${ }^{\circ} \mathrm{C}$ \\
\hline
\end{tabular}


Table 3 (continued)

\begin{tabular}{|c|c|c|}
\hline Climate variable & Variables & Unit \\
\hline Tmax_sm & Maximum summer temperature & ${ }^{\circ} \mathrm{C}$ \\
\hline Tmax_sp & Maximum spring temperature & ${ }^{\circ} \mathrm{C}$ \\
\hline Tmax_wt & Maximum winter temperature & ${ }^{\circ} \mathrm{C}$ \\
\hline $\operatorname{Tmax} 01$ & Maximum temperature 01 & ${ }^{\circ} \mathrm{C}$ \\
\hline $\operatorname{Tmax} 02$ & Maximum temperature 02 & ${ }^{\circ} \mathrm{C}$ \\
\hline Tmax03 & Maximum temperature 03 & ${ }^{\circ} \mathrm{C}$ \\
\hline Tmax04 & Maximum temperature 04 & ${ }^{\circ} \mathrm{C}$ \\
\hline Tmax05 & Maximum temperature 05 & ${ }^{\circ} \mathrm{C}$ \\
\hline Tmax06 & Maximum temperature 06 & ${ }^{\circ} \mathrm{C}$ \\
\hline $\operatorname{Tmax} 07$ & Maximum temperature 07 & ${ }^{\circ} \mathrm{C}$ \\
\hline Tmax08 & Maximum temperature 08 & ${ }^{\circ} \mathrm{C}$ \\
\hline Tmax09 & Maximum temperature 09 & ${ }^{\circ} \mathrm{C}$ \\
\hline $\operatorname{Tmax} 10$ & Maximum temperature 10 & ${ }^{\circ} \mathrm{C}$ \\
\hline $\operatorname{Tmax} 11$ & Maximum temperature 11 & ${ }^{\circ} \mathrm{C}$ \\
\hline $\operatorname{Tmax} 12$ & Maximum temperature 12 & ${ }^{\circ} \mathrm{C}$ \\
\hline Tmin_an & Minimum annual temperature & ${ }^{\circ} \mathrm{C}$ \\
\hline Tmin_at & Minimum autumn temperature & ${ }^{\circ} \mathrm{C}$ \\
\hline Tmin_sm & Minimum summer temperature & ${ }^{\circ} \mathrm{C}$ \\
\hline Tmin_sp & Minimum spring temperature & ${ }^{\circ} \mathrm{C}$ \\
\hline Tmin_wt & Minimum winter temperature & ${ }^{\circ} \mathrm{C}$ \\
\hline Tmin 01 & Minimum temperature 01 & ${ }^{\circ} \mathrm{C}$ \\
\hline $\operatorname{Tmin} 02$ & Minimum temperature 02 & ${ }^{\circ} \mathrm{C}$ \\
\hline Tmin 03 & Minimum temperature 03 & ${ }^{\circ} \mathrm{C}$ \\
\hline Tmin04 & Minimum temperature 04 & ${ }^{\circ} \mathrm{C}$ \\
\hline Tmin 05 & Minimum temperature 05 & ${ }^{\circ} \mathrm{C}$ \\
\hline Tmin06 & Minimum temperature 06 & ${ }^{\circ} \mathrm{C}$ \\
\hline Tmin07 & Minimum temperature 07 & ${ }^{\circ} \mathrm{C}$ \\
\hline Tmin 08 & Minimum temperature 08 & ${ }^{\circ} \mathrm{C}$ \\
\hline Tmin09 & Minimum temperature 09 & ${ }^{\circ} \mathrm{C}$ \\
\hline $\operatorname{Tmin} 10$ & Minimum temperature 10 & ${ }^{\circ} \mathrm{C}$ \\
\hline Tmin11 & Minimum temperature 11 & ${ }^{\circ} \mathrm{C}$ \\
\hline Tmin12 & Minimum temperature 12 & ${ }^{\circ} \mathrm{C}$ \\
\hline
\end{tabular}


Table 4 Climate variables used to calibrate the ensemble SDMs

\begin{tabular}{|c|c|c|}
\hline Acronym & Climate variable & Species \\
\hline SHM & Summer heat-moisture index & Picea abies \\
\hline PPT_at & Mean autumn precipitation & Picea abies \\
\hline FFP & Longest frost-free period & Picea abies \\
\hline TD & Continentality & Picea abies \\
\hline MCMT & Mean coldest month temperature & Picea abies \\
\hline SHM & Summer heat-moisture index & Abies alba \\
\hline EMT & Extreme minimum temperature & Abies alba \\
\hline TD & Continentality & Abies alba \\
\hline SHM & Summer heat-moisture index & Larix decidua \\
\hline Tave_sm & Average summer temperature & Larix decidua \\
\hline MWMT & Mean warmest month temperature & Larix decidua \\
\hline SHM & Summer heat-moisture index & Pinus sylvestris \\
\hline DDabove18 & Days with mean temperature above $18{ }^{\circ} \mathrm{C}$ & Pinus sylvestris \\
\hline Tmax_sp & Maximum spring temperature & Pinus sylvestris \\
\hline Tave_wt & Average winter temperature & Pinus sylvestris \\
\hline SHM & Summer heat-moisture index & Fagus sylvatica \\
\hline DDabove5 & Days with mean temperature above $5{ }^{\circ} \mathrm{C}$ & Fagus sylvatica \\
\hline PPT_sp & Mean spring precipitation & Fagus sylvatica \\
\hline EMT & Extreme minimum temperature & Fagus sylvatica \\
\hline Tave_sp & Average spring temperature & Fagus sylvatica \\
\hline DDbelow18 & Days with mean temperature below $18^{\circ} \mathrm{C}$ & Quercus petraea \\
\hline PPT_sm & Mean summer temperature & Quercus petraea \\
\hline MAT & Mean annual temperature & Quercus petraea \\
\hline DDabove 5 & Days with mean temperature above $5{ }^{\circ} \mathrm{C}$ & Quercus robur \\
\hline PPT_sm & Mean summer temperature & Quercus robur \\
\hline FFP & Longest frost-free period & Quercus robur \\
\hline Tmin_sp & Minimum spring temperature & Quercus robur \\
\hline MCMT & Mean coldest month temperature & Quercus robur \\
\hline
\end{tabular}



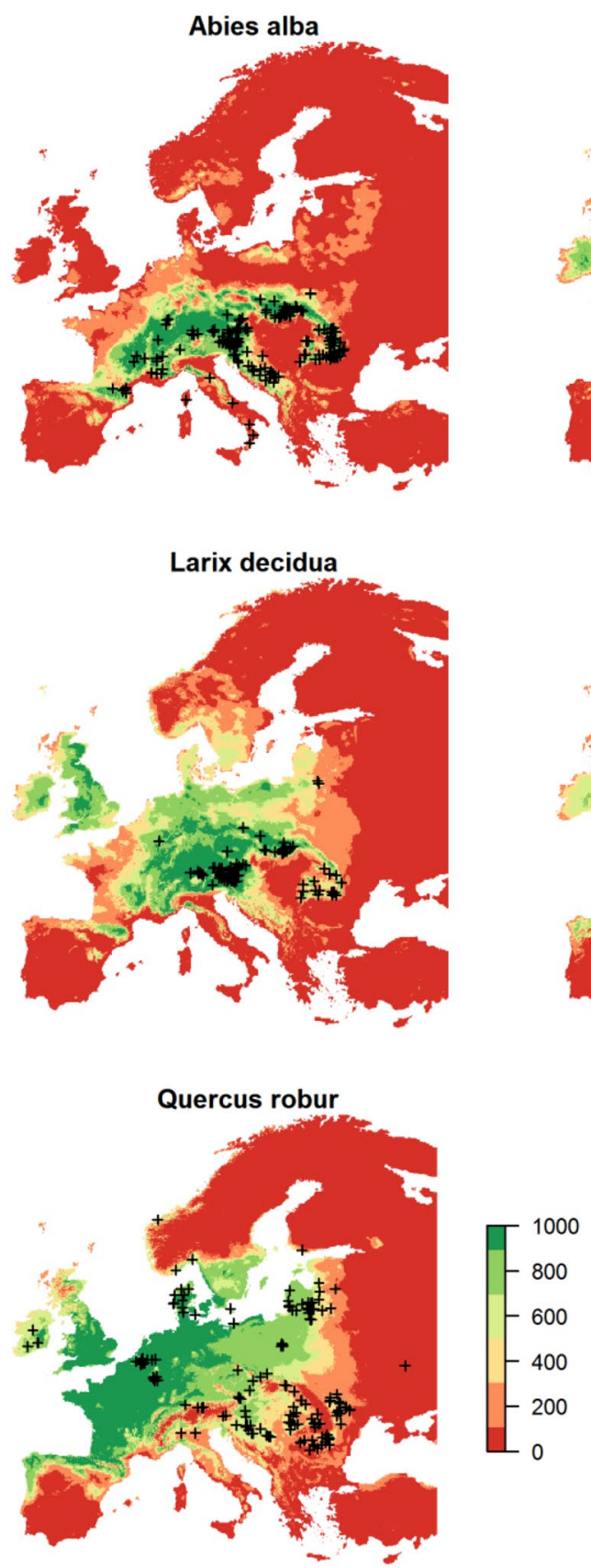
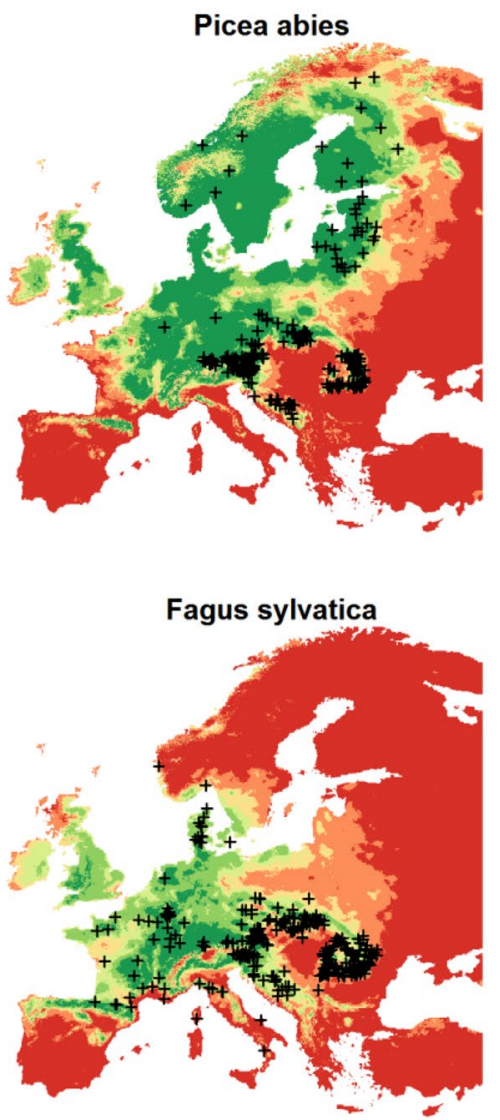
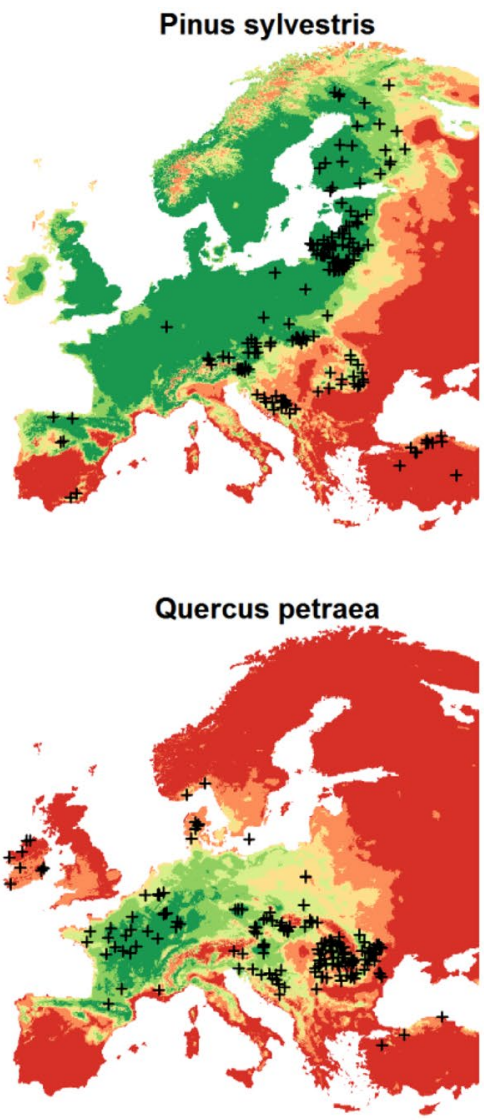

Fig. 3 Locations of the genetic conservation units (Lefèvre et al. 2013) plotted against the predictions of the ensemble SDMs for the period 1961-1990 for the seven target species of Europe. The prediction range 0-1000 refers to 0-100\% 
Table 5 Statistics for evaluation for each of the models used to develop the ensemble SDM for the seven tree species.

The summary of this model evaluation is presented in Table 1

\begin{tabular}{|c|c|c|c|c|c|c|}
\hline Criteria & Testing data & Evaluating data & Sensitivity & Specificity & Model & Species \\
\hline TSS & 0.921 & 0.916 & 96.718 & 94.925 & GLM & Abies alba \\
\hline ROC & 0.99 & 0.99 & 96.334 & 95.522 & GLM & Abies alba \\
\hline TSS & 0.936 & 0.933 & 96.377 & 96.887 & GBM & Abies alba \\
\hline ROC & 0.995 & 0.994 & 96.377 & 96.972 & GBM & Abies alba \\
\hline TSS & 0.949 & 0.939 & 97.357 & 96.588 & GAM & Abies alba \\
\hline ROC & 0.996 & 0.995 & 96.121 & 98.038 & GAM & Abies alba \\
\hline TSS & 0.936 & 0.932 & 95.396 & 97.825 & CTA & Abies alba \\
\hline $\mathrm{ROC}$ & 0.978 & 0.977 & 95.78 & 97.612 & CTA & Abies alba \\
\hline TSS & 0.962 & 0.956 & 97.4 & 98.209 & ANN & Abies alba \\
\hline $\mathrm{ROC}$ & 0.993 & 0.992 & 97.144 & 98.806 & ANN & Abies alba \\
\hline TSS & 0.743 & 0.745 & 79.199 & 95.309 & SRE & Abies alba \\
\hline ROC & 0.872 & 0.873 & 79.199 & 95.309 & SRE & Abies alba \\
\hline TSS & 0.927 & 0.92 & 96.633 & 95.394 & FDA & Abies alba \\
\hline $\mathrm{ROC}$ & 0.987 & 0.987 & 95.951 & 96.418 & FDA & Abies alba \\
\hline TSS & 0.929 & 0.927 & 96.292 & 96.418 & MARS & Abies alba \\
\hline ROC & 0.992 & 0.992 & 96.377 & 96.375 & MARS & Abies alba \\
\hline TSS & 0.998 & 0.968 & 98.167 & 98.635 & $\mathrm{RF}$ & Abies alba \\
\hline $\mathrm{ROC}$ & 1.00 & 0.998 & 98.679 & 98.337 & $\mathrm{RF}$ & Abies alba \\
\hline TSS & 0.872 & 0.884 & 94.246 & 94.2 & MAXENT* & Abies alba \\
\hline ROC & 0.979 & 0.981 & 95.482 & 93.262 & MAXENT* & Abies alba \\
\hline TSS & 0.802 & 0.804 & 93.126 & 87.25 & GLM & Fagus sylvatica \\
\hline $\mathrm{ROC}$ & 0.956 & 0.955 & 93.081 & 87.305 & GLM & Fagus sylvatica \\
\hline TSS & 0.825 & 0.818 & 92.991 & 88.806 & GBM & Fagus sylvatica \\
\hline ROC & 0.971 & 0.97 & 93.723 & 88.25 & GBM & Fagus sylvatica \\
\hline TSS & 0.826 & 0.827 & 94.375 & 88.384 & GAM & Fagus sylvatica \\
\hline ROC & 0.969 & 0.969 & 94.263 & 88.517 & GAM & Fagus sylvatica \\
\hline TSS & 0.859 & 0.85 & 93.543 & 91.441 & CTA & Fagus sylvatica \\
\hline ROC & 0.962 & 0.959 & 93.543 & 91.441 & CTA & Fagus sylvatica \\
\hline TSS & 0.849 & 0.846 & 93.993 & 90.585 & ANN & Fagus sylvatica \\
\hline $\mathrm{ROC}$ & 0.971 & 0.971 & 95.106 & 89.595 & ANN & Fagus sylvatica \\
\hline TSS & 0.6 & 0.586 & 75.307 & 83.337 & SRE & Fagus sylvatica \\
\hline ROC & 0.8 & 0.793 & 75.307 & 83.337 & SRE & Fagus sylvatica \\
\hline TSS & 0.794 & 0.793 & 90.899 & 88.395 & FDA & Fagus sylvatica \\
\hline $\mathrm{ROC}$ & 0.958 & 0.958 & 92.598 & 86.972 & FDA & Fagus sylvatica \\
\hline TSS & 0.811 & 0.809 & 92.789 & 88.072 & MARS & Fagus sylvatica \\
\hline ROC & 0.961 & 0.961 & 92.238 & 88.751 & MARS & Fagus sylvatica \\
\hline TSS & 0.994 & 0.935 & 97.278 & 96.187 & $\mathrm{RF}$ & Fagus sylvatica \\
\hline ROC & 1 & 0.994 & 97.188 & 96.343 & $\mathrm{RF}$ & Fagus sylvatica \\
\hline TSS & 0.755 & 0.752 & 93.61 & 81.525 & MAXENT* & Fagus sylvatica \\
\hline ROC & 0.926 & 0.927 & 93.835 & 81.381 & MAXENT* & Fagus sylvatica \\
\hline TSS & 0.858 & 0.867 & 95.254 & 91.423 & GLM & Larix decidua \\
\hline ROC & 0.975 & 0.976 & 95.548 & 91.277 & GLM & Larix decidua \\
\hline TSS & 0.894 & 0.891 & 94.765 & 94.201 & GBM & Larix decidua \\
\hline ROC & 0.987 & 0.985 & 94.716 & 94.591 & GBM & Larix decidua \\
\hline TSS & 0.91 & 0.911 & 96.282 & 94.786 & GAM & Larix decidua \\
\hline ROC & 0.988 & 0.987 & 95.89 & 95.224 & GAM & Larix decidua \\
\hline TSS & 0.92 & 0.906 & 96.233 & 94.396 & CTA & Larix decidua \\
\hline $\mathrm{ROC}$ & 0.978 & 0.973 & 96.233 & 94.396 & CTA & Larix decidua \\
\hline TSS & 0.924 & 0.923 & 96.722 & 95.614 & ANN & Larix decidua \\
\hline ROC & 0.991 & 0.989 & 95.841 & 96.686 & ANN & Larix decidua \\
\hline TSS & 0.656 & 0.651 & 77.153 & 87.914 & SRE & Larix decidua \\
\hline
\end{tabular}


Table 5 (continued)

\begin{tabular}{|c|c|c|c|c|c|c|}
\hline Criteria & Testing data & Evaluating data & Sensitivity & Specificity & Model & Species \\
\hline ROC & 0.828 & 0.825 & 77.153 & 87.914 & SRE & Larix decidua \\
\hline TSS & 0.863 & 0.871 & 95.548 & 91.52 & FDA & Larix decidua \\
\hline ROC & 0.974 & 0.974 & 95.303 & 92.251 & FDA & Larix decidua \\
\hline TSS & 0.878 & 0.888 & 96.526 & 92.3 & MARS & Larix decidua \\
\hline ROC & 0.981 & 0.98 & 96.575 & 92.3 & MARS & Larix decidua \\
\hline TSS & 0.997 & 0.96 & 98.386 & 97.661 & $\mathrm{RF}$ & Larix decidua \\
\hline ROC & 1 & 0.996 & 98.337 & 97.758 & $\mathrm{RF}$ & Larix decidua \\
\hline TSS & 0.735 & 0.754 & 95.01 & 80.361 & MAXENT* & Larix decidua \\
\hline ROC & 0.917 & 0.924 & 95.01 & 80.409 & MAXENT* & Larix decidua \\
\hline TSS & 0.834 & 0.834 & 91.633 & 91.827 & GLM & Pice abies \\
\hline ROC & 0.975 & 0.975 & 91.93 & 91.58 & GLM & Pice abies \\
\hline TSS & 0.895 & 0.898 & 96.673 & 93.09 & GBM & Pice abies \\
\hline ROC & 0.986 & 0.987 & 96.615 & 93.192 & GBM & Pice abies \\
\hline TSS & 0.893 & 0.897 & 95.143 & 94.591 & GAM & Pice abies \\
\hline ROC & 0.987 & 0.987 & 94.692 & 95.171 & GAM & Pice abies \\
\hline TSS & 0.921 & 0.917 & 97.631 & 94.028 & CTA & Pice abies \\
\hline ROC & 0.979 & 0.978 & 97.631 & 94.028 & CTA & Pice abies \\
\hline TSS & 0.875 & 0.873 & 96.393 & 90.915 & ANN & Pice abies \\
\hline ROC & 0.965 & 0.965 & 96.484 & 90.889 & ANN & Pice abies \\
\hline TSS & 0.643 & 0.643 & 75.589 & 88.662 & SRE & Pice abies \\
\hline ROC & 0.821 & 0.821 & 75.589 & 88.662 & SRE & Pice abies \\
\hline TSS & 0.829 & 0.832 & 91.553 & 91.648 & FDA & Pice abies \\
\hline ROC & 0.974 & 0.975 & 93.334 & 90.104 & FDA & Pice abies \\
\hline TSS & 0.861 & 0.865 & 93.419 & 93.073 & MARS & Pice abies \\
\hline ROC & 0.979 & 0.98 & 94.35 & 92.228 & MARS & Pice abies \\
\hline TSS & 0.998 & 0.985 & 99.515 & 98.968 & $\mathrm{RF}$ & Pice abies \\
\hline ROC & 1 & 0.998 & 99.538 & 98.968 & $\mathrm{RF}$ & Pice abies \\
\hline TSS & 0.606 & 0.604 & 94.019 & 66.362 & MAXENT* & Pice abies \\
\hline ROC & 0.88 & 0.88 & 94.492 & 65.953 & MAXENT* & Pice abies \\
\hline TSS & 0.787 & 0.789 & 91.278 & 87.63 & GLM & Pinus sylvestris \\
\hline ROC & 0.958 & 0.958 & 91.74 & 87.281 & GLM & Pinus sylvestris \\
\hline TSS & 0.872 & 0.864 & 96.999 & 89.344 & GBM & Pinus sylvestris \\
\hline ROC & 0.976 & 0.974 & 94.859 & 91.808 & GBM & Pinus sylvestris \\
\hline TSS & 0.857 & 0.859 & 94.526 & 91.366 & GAM & Pinus sylvestris \\
\hline ROC & 0.976 & 0.976 & 93.778 & 92.26 & GAM & Pinus sylvestris \\
\hline TSS & 0.91 & 0.9 & 97.731 & 92.249 & CTA & Pinus sylvestris \\
\hline ROC & 0.968 & 0.964 & 97.682 & 92.362 & CTA & Pinus sylvestris \\
\hline TSS & 0.886 & 0.886 & 96.08 & 92.537 & ANN & Pinus sylvestris \\
\hline ROC & 0.966 & 0.964 & 95.789 & 92.875 & ANN & Pinus sylvestris \\
\hline TSS & 0.572 & 0.579 & 76.21 & 81.686 & SRE & Pinus sylvestris \\
\hline ROC & 0.786 & 0.789 & 76.21 & 81.686 & SRE & Pinus sylvestris \\
\hline TSS & 0.803 & 0.802 & 91.638 & 88.533 & FDA & Pinus sylvestris \\
\hline ROC & 0.961 & 0.96 & 93.009 & 87.517 & FDA & Pinus sylvestris \\
\hline TSS & 0.829 & 0.831 & 95.176 & 87.917 & MARS & Pinus sylvestris \\
\hline ROC & 0.966 & 0.966 & 94.628 & 88.584 & MARS & Pinus sylvestris \\
\hline TSS & 0.998 & 0.975 & 99.048 & 98.47 & $\mathrm{RF}$ & Pinus sylvestris \\
\hline ROC & 1 & 0.997 & 99.145 & 98.44 & $\mathrm{RF}$ & Pinus sylvestris \\
\hline TSS & 0.503 & 0.506 & 93.101 & 57.479 & MAXENT* & Pinus sylvestris \\
\hline ROC & 0.819 & 0.816 & 93.413 & 57.243 & MAXENT* & Pinus sylvestris \\
\hline TSS & 0.849 & 0.851 & 91.782 & 93.277 & GLM & Quercus robur \\
\hline ROC & 0.976 & 0.977 & 91.73 & 93.418 & GLM & Quercus robur \\
\hline
\end{tabular}


Table 5 (continued)

\begin{tabular}{|c|c|c|c|c|c|c|}
\hline Criteria & Testing data & Evaluating data & Sensitivity & Specificity & Model & Species \\
\hline TSS & 0.889 & 0.892 & 96.048 & 93.175 & GBM & Quercus robur \\
\hline ROC & 0.985 & 0.986 & 94.818 & 94.517 & GBM & Quercus robur \\
\hline TSS & 0.88 & 0.882 & 94.87 & 93.328 & GAM & Quercus robur \\
\hline ROC & 0.983 & 0.984 & 95.342 & 92.97 & GAM & Quercus robur \\
\hline TSS & 0.91 & 0.909 & 96.218 & 94.696 & CTA & Quercus robur \\
\hline ROC & 0.977 & 0.978 & 96.218 & 94.696 & CTA & Quercus robur \\
\hline TSS & 0.915 & 0.917 & 96.794 & 94.875 & ANN & Quercus robur \\
\hline ROC & 0.984 & 0.984 & 96.336 & 95.386 & ANN & Quercus robur \\
\hline TSS & 0.718 & 0.72 & 76.93 & 95.066 & SRE & Quercus robur \\
\hline ROC & 0.859 & 0.86 & 76.93 & 95.066 & SRE & Quercus robur \\
\hline TSS & 0.844 & 0.844 & 92.423 & 92.037 & FDA & Quercus robur \\
\hline ROC & 0.974 & 0.977 & 92.044 & 92.523 & FDA & Quercus robur \\
\hline TSS & 0.859 & 0.857 & 92.58 & 93.175 & MARS & Quercus robur \\
\hline ROC & 0.977 & 0.979 & 92.306 & 93.494 & MARS & Quercus robur \\
\hline TSS & 0.996 & 0.965 & 98.574 & 97.968 & RF & Quercus robur \\
\hline ROC & 1 & 0.998 & 98.09 & 98.556 & $\mathrm{RF}$ & Quercus robur \\
\hline TSS & 0.778 & 0.787 & 95.878 & 82.848 & MAXENT* & Quercus robur \\
\hline ROC & 0.943 & 0.946 & 95.773 & 82.975 & MAXENT* & Quercus robur \\
\hline TSS & 0.754 & 0.747 & 94.685 & 80.019 & GLM & Quercus petraea \\
\hline ROC & 0.942 & 0.945 & 93.45 & 81.709 & GLM & Quercus petraea \\
\hline TSS & 0.789 & 0.788 & 89.93 & 88.988 & GBM & Quercus petraea \\
\hline ROC & 0.962 & 0.962 & 90.629 & 88.401 & GBM & Quercus petraea \\
\hline TSS & 0.806 & 0.805 & 91.865 & 88.565 & GAM & Quercus petraea \\
\hline ROC & 0.962 & 0.962 & 91.072 & 89.739 & GAM & Quercus petraea \\
\hline TSS & 0.856 & 0.834 & 93.986 & 89.458 & CTA & Quercus petraea \\
\hline ROC & 0.957 & 0.953 & 93.986 & 89.458 & CTA & Quercus petraea \\
\hline TSS & 0.831 & 0.835 & 92.96 & 90.514 & ANN & Quercus petraea \\
\hline ROC & 0.961 & 0.963 & 92.821 & 90.679 & ANN & Quercus petraea \\
\hline TSS & 0.643 & 0.658 & 79.674 & 86.124 & SRE & Quercus petraea \\
\hline ROC & 0.821 & 0.829 & 79.674 & 86.124 & SRE & Quercus petraea \\
\hline TSS & 0.766 & 0.764 & 92.051 & 84.269 & FDA & Quercus petraea \\
\hline ROC & 0.949 & 0.951 & 90.49 & 86.194 & FDA & Quercus petraea \\
\hline TSS & 0.782 & 0.783 & 95.455 & 82.883 & MARS & Quercus petraea \\
\hline ROC & 0.952 & 0.953 & 95.618 & 82.789 & MARS & Quercus petraea \\
\hline TSS & 0.992 & 0.901 & 95.431 & 94.811 & $\mathrm{RF}$ & Quercus petraea \\
\hline ROC & 1 & 0.989 & 95.501 & 94.811 & $\mathrm{RF}$ & Quercus petraea \\
\hline TSS & 0.702 & 0.685 & 92.238 & 76.286 & MAXENT** & Quercus petraea \\
\hline ROC & 0.9 & 0.898 & 94.126 & 74.618 & MAXENT** & Quercus petraea \\
\hline
\end{tabular}

*MAXENT Tsuruoka

Table 6 Predicted probability of occurrence of the seven target species predicted for independent data of European genetic conservation units from Lefèvre et al. (2013). Probability class of 0-40, and 40-60 were assumed to be incorrectly predicted and $>60 \%$ as correctly predicted by the SDMs

\begin{tabular}{llllllll}
\hline \multirow{2}{*}{ Probability class } & \multicolumn{2}{l}{ Number of genetic conservation units in respective probability class } \\
\cline { 2 - 7 } & A alba & P abies & P sylvestris & L decidua & F sylvatica & Q petraea & Q robur \\
\hline $0-40$ & 4 & 1 & 17 & 2 & 5 & 26 & 23 \\
$40-60$ & 9 & 16 & 24 & 9 & 38 & 6 & 18 \\
$60-80$ & 32 & 34 & 18 & 6 & 96 & 95 \\
$80-100$ & 182 & 318 & 152 & 108 & 208 & 86 & 82 \\
\hline
\end{tabular}


Acknowledgement We acknowledge the cooperation of all participating institutes of the Interreg CE-SUSTREE project in compiling the dataset. We also acknowledge Dr. Laura Dobor and Dr. Tomáš Hlásny supported by the grant "EVA4.000, No. CZ.02.1.01/ 0.0/0.0/16_019/0000803" financed by OP RDE for their contribution to acquiring the EURO-CORDEX climate data.

Funding The research was funded by INTERREG-Central Europe program (Project SUSTREE: Conservation and sustainable utilization of forest tree diversity in climate change).

Open Access This article is licensed under a Creative Commons Attribution 4.0 International License, which permits use, sharing, adaptation, distribution and reproduction in any medium or format, as long as you give appropriate credit to the original author(s) and the source, provide a link to the Creative Commons licence, and indicate if changes were made. The images or other third party material in this article are included in the article's Creative Commons licence, unless indicated otherwise in a credit line to the material. If material is not included in the article's Creative Commons licence and your intended use is not permitted by statutory regulation or exceeds the permitted use, you will need to obtain permission directly from the copyright holder. To view a copy of this licence, visit http://creativecommons.org/licenses/by/4.0/.

\section{References}

Akaike H (1974) A new look at the statistical model identification. IEEE Trans Automat Control. https://doi.org/10.1109/TAC.1974.1100705

Allen CD, Macalady AK, Chenchouni H et al (2010) A global overview of drought and heat-induced tree mortality reveals emerging climate change risks for forests. For Ecol Manage 259:660-684. https://doi.org/10.1016/j.foreco.2009.09.001

Allouche O, Tsoar A, Kadmon R (2006) Assessing the accuracy of species distribution models: prevalence, kappa and the true skill statistic (TSS). J Appl Ecol 43:1223-1232. https://doi.org/10.1111/ j.1365-2664.2006.01214.x

Benito Garzón M, Alía R, Robson TM, Zavala MA (2011) Intra-specific variability and plasticity influence potential tree species distributions under climate change. Glob Ecol Biogeogr 20:766-778. https://doi.org/10.1111/j.1466-8238.2010.00646.x

Booth GD, Niccolucci MJ, Schuster EG (1994) Identifying proxy sets in multiple linear-regression - an aid to better coefficient interpretation. USDA For Serv Intermt Res Stn Res Pap

Breiman L (2001) Random forests. Mach Learn 45:5-32. https://doi. org/10.1023/A:1010933404324

Chakraborty D, Schueler S, Lexer MJ, Wang T (2019) Genetic trials improve the transfer of Douglas-fir distribution models across continents. Ecography 42:88-101. https://doi.org/10.1111/ecog.03888

Chakraborty D, Dobor L, Hlásny T, Schueler S (2020) High-resolution gridded climate data for Europe based on bias-corrected EUROCORDEX: the ECLIPS-2.0 dataset [Zenodo: https://doi.org/10.5281/ zenodo.3952159]

Chakraborty D, Móricz N, Rasztovits E, Dobor L, Schueler S (2020) Provisioning forest and conservation science with European tree species distribution models under climate change. V1. Zenodo. https://doi.org/10.5281/zenodo.3686918

Coetzee BWT, Robertson MP, Erasmus BFN et al (2009) Ensemble models predict important bird areas in southern Africa will become less effective for conserving endemic birds under climate change. Glob Ecol Biogeogr 18:701-710. https://doi.org/10.1111/j. 1466-8238.2009.00485.x

Craney TA, Surles JG (2002) Model-dependent variance inflation factor cutoff values. Qual Eng 14(3):391-403. https://doi.org/10.1081/ QEN-120001878
Dyderski MK, Paź S, Frelich LE, Jagodziński AM (2018) How much does climate change threaten European forest tree species distributions? Glob Chang Biol 24:1150-1163. https://doi.org/10.1111/gcb.13925

European Environmental Agency (2006) European forest types-the European forest types-categories and types for sustainable forest management reporting and policy. EEA technical report No 9/2006. ISBN: 2-9167-886-4

Garate-Escamilla H, Hampe A, Vizcaino-Palomar N et al (2019) Rangewide variation in local adaptation and phenotypic plasticity of fitness-related traits in Fagus sylvatica and their implications under climate change. bioRxiv 513515. https://doi.org/10.1101/513515

Giorgi F, Jones C, Asrar GR (2009) Addressing climate information needs at the regional level: the CORDEX framework. World Meteorol Organ Bull 58:175-183. https://doi.org/10.1109/ICASSP. 2009.4960141

Guisan A, Tingley R, Baumgartner JB et al (2013) Predicting species distributions for conservation decisions. Ecol Lett 16:1424-1435. https://doi.org/10.1111/ele.12189

Hamann A, Aitken SN (2013) Conservation planning under climate change: accounting for adaptive potential and migration capacity in species distribution models. Divers Distrib 19:268-280. https://doi. org/10.1111/j.1472-4642.2012.00945.x

Hanewinkel M, Cullmann DA, Schelhaas M-JJ et al (2013) Climate change may cause severe loss in the economic value of European forest land. Nat Clim Chang 3:203-207. https://doi.org/10.1038/ nclimate 1687

Härtl FH, Barka I, Hahn WA et al (2016) Multifunctionality in European mountain forests - an optimization under changing climatic conditions. Can J For Res 46:163-171. https://doi.org/10.1139/ cjfr-2015-0264

Hiederer R , Houston Durrant T, Micheli E (2011) Evaluation of BioSoil demonstration project—soil data analysis.—Vol. 24729 of EUR-Scientific and Technical Research, Publications Office of the European Union.

Houston Durrant T, San-Miguel-Ayanz J, Schulte E, Suarez Meyer A (2011) Evaluation of BioSoil demonstration project: forest biodiversity-analysis of biodiversity module, vol. 24777 of EUR-Scientific and Technical Research (Publications Office of the European Union, 2011).

Jacob D, Petersen J, Eggert B et al (2014) EURO-CORDEX: New high-resolution climate change projections for European impact research. Reg Environ Chang. https://doi.org/10.1007/s10113013-0499-2

Kreyling J, Schmid S, Aas G (2015) Cold tolerance of tree species is related to the climate of their native ranges. J Biogeogr 42:156166. https://doi.org/10.1111/jbi.12411

Lefèvre F, Koskela J, Hubert J et al (2013) Dynamic Conservation of Forest Genetic Resources in 33 European Countries. Conserv Biol. https://doi.org/10.1111/j.1523-1739.2012.01961.x

Maroschek M, Seidl R, Netherer S, Lexer MJ (2009) Climate change impacts on goods and services of European mountain forests. Unasylva 60(231):76-80

Mauri A, Strona G, San-Miguel-Ayanz J (2017) EU-Forest, a highresolution tree occurrence dataset for Europe. Sci Data 4:1-8. https://doi.org/10.1038/sdata.2016.123

Mcshea WJ (2014) What are the roles of species distribution models in conservation planning? Environ Conserv 41:93-96

Mina M, Bugmann H, Cordonnier T et al (2017) Future ecosystem services from European mountain forests under climate change. J Appl Ecol 54:389-401. https://doi.org/10.1111/1365-2664.12772

Moreno A, Hasenauer H (2016) Spatial downscaling of European climate data. Int J Climatol 36:1444-1458. https://doi.org/10.1002/ joc. 4436

O’Neill GA, Hamann A, Wang T (2008) Accounting for population variation improves estimates of the impact of climate change on 
species' growth and distribution. J Appl Ecol. https://doi.org/10. 1111/j.1365-2664.2008.01472.x

Pontius RG, Parmentier B (2014) Recommendations for using the relative operating characteristic (ROC). Landsc Ecol 29:367-382. https://doi.org/10.1007/s10980-013-9984-8

R Core Team (2016) R Core Team R. R A Lang Environ Stat Comput R Found Stat Comput, Vienna, Austria. https://www.R-project.org

Ramirez-Villegas J, Jarvis A (2010) Downscaling global circulation model outputs: the Delta method. Policy Analalysis working paper 1. International centre for Tropical Agriculture available at http:// ccafs-climate.org/downloads/docs/Downscaling-WP-01.pdf

Reyer C, Lasch-Born P, Suckow F et al (2014) Projections of regional changes in forest net primary productivity for different tree species in Europe driven by climate change and carbon dioxide. Ann For Sci 71:211-225. https://doi.org/10.1007/s13595-013-0306-8

Scheffers BR, De Meester L, Bridge TCL et al (2016) The broad footprint of climate change from genes to biomes to people. Science 354/6313, aaf7671 https://doi.org/10.1126/science.aaf7671

Schueler S, Falk W, Koskela J et al (2014) Vulnerability of dynamic genetic conservation units of forest trees in Europe to climate change. Glob Chang Biol 20:1498-1511. https://doi.org/10.1111/ gcb. 12476

Seidl R, Schelhaas MJ, Lexer MJ (2011) Unraveling the drivers of intensifying forest disturbance regimes in Europe. Glob Chang Biol 17:2842-2852. https://doi.org/10.1111/j.1365-2486.2011.02452.x

Seidl R, Schelhaas MJ, Rammer W, Verkerk PJ (2014) Increasing forest disturbances in Europe and their impact on carbon storage. Nat Clim Chang 4:806-810. https://doi.org/10.1038/nclimate2318

Senay SD, Worner SP, Ikeda T (2013) Novel three-step pseudo-absence selection technique for improved species distribution modelling. PLoS One 8:e71218. https://doi.org/10.1371/journal.pone.0071218

Sykes MT, Prentice IC, Cramer W (1996) A bioclimatic model for the potential distributions of north European tree species under present and future climates. J Biogeogr 23:203-233
Thompson CG, Kim RS, Aloe AM, Becker BJ (2017) Extracting the variance in flation factor and other multicollinearity diagnostics from typical regression results. Basic Appl Soc Psych. https://doi. org/10.1080/01973533.2016.1277529

Thuiller W, Albert C, Araújo MB et al (2008) Predicting global change impacts on plant species' distributions: future challenges. Perspect Plant Ecol Evol Syst 9:137-152. https://doi.org/10.1016/j.ppees. 2007.09.004

Thuiller W, Georges D, Engler R (2016) biomod2: Ensemble platform for species distribution modeling. R Packag version 2:r560

Thurm EA, Hernandez L, Baltensweiler A et al (2018) Alternative tree species under climate warming in managed European forests. For Ecol Manage 430:485-497. https://doi.org/10.1016/j. foreco.2018.08.028

Valladares F, Matesanz S, Guilhaumon F et al (2014) The effects of phenotypic plasticity and local adaptation on forecasts of species range shifts under climate change. Ecol Lett 17:1351-1364. https://doi. org/10.1111/ele.12348

van Vuuren DP, Edmonds J, Kainuma M et al (2011) The representative concentration pathways: an overview. Clim Change 109:5-31. https://doi.org/10.1007/s10584-011-0148-z

Yang W, Andreasson J, Graham P, Olsson J (2010) Distribution based scaling to improve usability of RCM regional climate model projections for hydrological climate change impact studies. Hydrol Res 41:211-229. https://doi.org/10.2166/nh.2010.004

Zimmermann NE, Edwards TC, Graham CH et al (2010) New trends in species distribution modelling. Ecography (Cop) 33:985-989. https://doi.org/10.1111/j.1600-0587.2010.06953.x

Zurell D, Franklin J, König C et al (2020) A standard protocol for reporting species distribution models. Ecography 01 June 2020 https://doi.org/10.1111/ecog.04960 